\title{
I. Networks of the Unnamed and Medical Interventions in Colonial Cameroon
}

\author{
SARAH RUNCIE
}

Historians focusing on periods of colonial rule and enslavement have long grappled with how to uncover the names, voices, and agency of the oppressed from an archival record often written by the powerful. As scholars have begun to explore the use of digital tools and visualizations of data, moreover, some have raised pertinent questions about how one might represent such "absences" in a visual form. ${ }^{1}$

As a complete novice of network analysis participating in the Viral Networks workshop, these questions quickly arose for me as well. Exploring network analysis offered an opportunity to work in new ways with my research on the history of mobile health teams in French colonial Cameroon. These teams, which were generally led by Europeans but staffed primarily by Cameroonian medical auxiliaries, traveled across the territory and became the primary basis of biomedical intervention in rural areas beginning in the 1920s. French colonial doctors also left detailed records about the work of the mobile teams. While I was at first intrigued by the sheer novelty of turning some of these records into datasets and visualizations, I quickly developed a healthy scholarly skepticism about producing visualizations based on colonial medical records. This experience led me to rethink my approach to the data drawing on my own training as a historian of Africa.

Scholars of colonialism have highlighted how we might best approach colonial records as representative of the logic, aspirations, and blind spots of the state. ${ }^{2}$ In the case of the mobile health team service, the aspiration of reaching Cameroonians as patients and recording this encounter was not only a medical or clerical task, 
but one of significant political importance. ${ }^{3}$ Moreover, historians of disease and health in Africa have long pointed to the multiplicity of forms of healing in Africa during the colonial period, and they have questioned the hegemony of biomedicine in this context. ${ }^{4}$ Critical methodological questions thus arise for the historian wishing to productively use colonial records in a new digital medium. How can we use data for network analysis while recognizing complexity? Does creating visualizations based on colonial records reify this information while obscuring other forms of information about medicine in colonial contexts that might be essential? Put another way, what kinds of questions about colonial medical records might network analysis be most helpful in exploring?

Through my participation in the Viral Networks workshop, I first aimed to draw on network analysis to explore the question of how colonial mobile health teams spread biomedical intervention in Cameroon. Examining networks presents a potential opportunity to move beyond analysis of the mobile health teams through description of an individual visit or in aggregate terms of how many people they examined, and instead move into closer analysis of how the individual visits of the teams were connected to one another. But what data do we have to connect these teams and visits to one another?

A significant pitfall of using colonial data to analyze the work of the teams arises in who is named and who is not named in these records. If we prioritize seeing the work of the teams as driven by specific, named, historical actors, for example, then we run the risk of focusing exclusively on the work of French doctors and thus reproducing a colonial narrative. This dilemma speaks to larger historiographical trends in the history of medicine that have turned away from a "diffusionist" model that explains medicine as something that traveled from the European metropole to African or Asian colonies. Scholars have rather highlighted how medical practices and forms of knowledge were actively, and messily, created on the ground in the colonies. ${ }^{5}$ In my own research, one of my main focuses has been the work of Cameroonians as biomedical 
workers in the colonial period and beyond. Yet, in the colonial records I worked with for this project, the Cameroonians constituting the clear majority of labor of the mobile health teams go unnamed. Do network analysis and data visualization have the potential to intervene in these historiographical questions by disrupting an idea of French colonial doctors as the "drivers" of medical intervention in the colonies and towards a focus on the work of known, but unnamed, African actors? This piece aims to provide a concrete example of how historians can bring these kinds of scholarly orientations to bear on choices in using data for network analysis.

\section{Networks and Naming in Medical Work}

Many accounts of the French mobile health teams in Africa, both scholarly and otherwise, focus on the work of one man in their creation and spread. French military doctor Eugène Jamot formulated the early mobile health team model to address an epidemic of sleeping sickness raging in Central Africa in the 1920s. The innovation of the teams was their mobility and the idea that medical personnel would travel directly to people within set geographic parameters, rather than only interacting with those who visited hospitals or dispensaries. Jamot continues to occupy an immense place in both scholarship and popular remembrances of French colonial medicine. ${ }^{6}$ A bust of Jamot sits in Cameroon's capital city of Yaoundé to this day.

The work of the teams, however, extended long beyond Jamot's death in 1937. After World War II, an expanded mobile health service called the Service d'Hygiène Mobile et de Prophylaxie (SHMP) became the primary basis of rural health intervention in France's African colonies. In addition to continuing to screen and treat sleeping sickness, the teams expanded their mandate after the war to include focus on other endemic and epidemic diseases such as smallpox, leprosy, and malaria. Run by French military doctors and staffed by 
African auxiliaries, these teams traveled on circuits through villages and gathered local people for examination, and sometimes treatment, in coordination with local authorities. The teams thus expanded biomedical interventions and diagnosis to new parts of Cameroon, and to new individuals, through their travel. Through acts such as physical examinations, injections, and vaccinations, the teams represented a key component of France's medical work in colonial Cameroon and elsewhere in Africa.

Cameroonian historian Wang Sonne broke new ground in moving analysis of the teams away from a singular focus on Jamot and other French military doctors to examine closely the role of Cameroonian medical auxiliaries. ${ }^{7}$ Since Soone's early work, a broader historical scholarship has also grown focused on African "intermediaries" of the colonial state. This scholarship has highlighted how "Africans in the lower ranks of the colonial bureaucracy often held positions that bestowed little official authority, but in practice the occupants of these positions functioned, somewhat paradoxically, as the hidden linchpins of colonial rule." 8 Africans thus played key roles in the functioning of the colonial state in realms such as teaching, forestry and certainly medical services. ${ }^{9}$ Other scholars of Cameroon and colonial medicine have followed suit, continuing to elaborate on the work of African auxiliaries and also examining the mobile teams as key sites for the unfolding of the agendas, contradictions, and disasters of French colonial medicine in Africa. ${ }^{10}$ These works, including my own, have relied on qualitative assessments in their use of colonial records.

Network analysis offers a potential opportunity to use these same records in new ways to examine the fine-grain work of individual people, or groups of people, and how they connected in their work across Cameroon. In line with my broader scholarship, I am most interested in how visualizations might help to continue to challenge a portrait of the mobile health teams as an endeavor driven by a small number of French military doctors and re-enforce a focus on the Cameroonian medical auxiliaries performing the labor of the teams. 
Significant challenges in visually representing this work arise due to hierarchies of authority over the teams and uneven naming of participants in the archival record. These hierarchies existed along lines of both "European" versus "African" medical personnel and in terms of the degree of medical training. The medical personnel leading each individual mobile team often show up most clearly as individuals in the archival record, although there are notable disparities in how the work of Africans leading the teams is described. The one to two Cameroonian medical personnel who led the teams in the late 1940s and early 1950s were a target of major critique. In a 1950 report, for example, the head of the mobile service for Cameroon complained that African medical personnel did not have the necessary "upper hand" with the population to ensure success. ${ }^{11}$ In this regard, although the vast majority of the personnel of the mobile teams were African medical auxiliaries, colonial officials framed white Europeans as the drivers of the spread of biomedical intervention through the mobile health teams. The colonial record reproduces this interpretative slant in who it names and does not name. Some records from the late 1940s name the person heading each mobile team, both European and African, although these specifics slip out of many of the reports in the 1950s. No details other than professional rank, such as nurse, however, are provided for the African medical auxiliaries performing the work of the mobile health teams.

The dilemmas presented by this project reflect questions that humanities scholars have fruitfully explored in relation to digital humanities. Engaging the archive of slavery in the United States in her article, "The Images of Absence: Archival Silence, Data Visualization, and James Hemings," Lauren F. Klein offers a powerful exploration of how humanities scholars can think about maintaining the kinds of questions they ask and approaches to sources in delving into work in the digital humanities. Specifically, in examining the issue of "silences in the archive" of slavery, she proposes methods to try to move away from this focus on absence to bring forth pathways, connections and the "distributed impact of the labor" 
of people seemingly lost to archival silences. Using digital tools in this way, she argues, "reframes the archive itself as a site of action, rather than as a record of fixity or loss." 12 The connection between Klein's article and my own project point to a shared challenge of historians wishing to explore data visualizations but working on subjects in which the voices, or even the names, of certain actors are rendered invisible by archival sources.

In this spirit, I offer three visualizations of the work of mobile health teams in colonial Cameroon that are identical apart from who they name or don't name. Through these visualizations I aim to highlight the kinds of small but meaningful choices that historians face in visually presenting data. Cameroonian medical auxiliaries played a key role in the work of the mobile health teams, but they remain a nameless mass in the colonial records I draw on here. To paraphrase Klein, I seek to explore here how data visualization can be utilized to move from a framework of namelessness of medical auxiliaries to one of networks of labor.

\section{Data and Methodology}

This network analysis draws on records produced directly by the mobile health service in Cameroon (SHMP) and published either in annual reports produced by the broader colonial Public Health Service in Cameroon, or in French governmental reports on Cameroon to the United Nations. The United Nations reports are available in the Columbia University library and I collected the annual reports of the Public Health Service through archival research in France. For this piece, I have used data on the SHMP only for the years 1947-1951.

Using these records, I compiled a database using Microsoft Access that lists each known visit of a mobile health team from 1947-1951. The database includes information on the location and date of the visit, the recorded population of that location, the number of people examined by the mobile team, and the number of people given 
either a smallpox vaccination or a mixed smallpox/yellow fever vaccine. A connected table captures information about the individual mobile team performing the visit, such as their numerical designation within Cameroon's SHMP (i.e., Team 5), the name of the person leading that team, and the professional rank of this person. A limitation of my database is inconsistency of information. For some years, for example, the reports I used do not provide the precise dates of visits of the mobile teams, the names of the teams, or the names of the team heads.

Three visualizations were created through Cytoscape with this dataset. These three visualizations highlight the work of the teams in three forms. Figure 1.1 frames the network of mobile teams through the name of the team head, when available. Figure 1.2 highlights the professional rank of the team head. Figure 1.3 removes all information about the team head and highlights the administrative designation of the team, when available. All of these

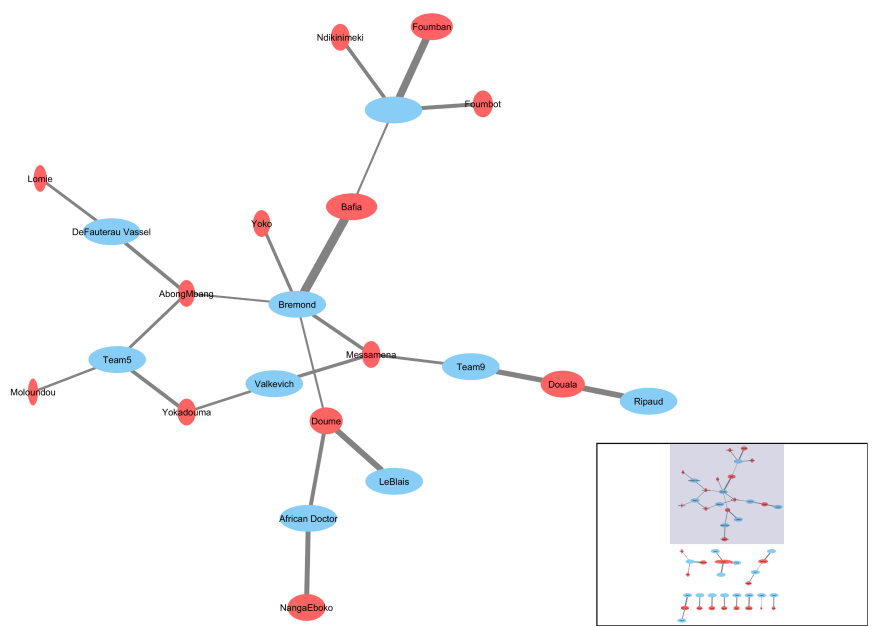

Figure 1.1: Team head names shown, mobile health team Visits, 1947-1951 (portion of graph) The Blue ovals (nodes) represent the mobile health teams and the red represents locations of the visits. The red oval size is based on the recorded population for that location. The width of the connecting lines (edges) represents the number of patients seen at each visit. 
graphs are based off an original Cytoscape query and visualization using my database and created by Nathaniel Porter of Virginia Tech.

In figure 1.1, the names of the team heads are highlighted and this visualization supports a framing of the mobile health teams through the work of named historical actors. We can see that certain team heads led multiple mobile health team visits and thus were contributors to the geographic reach of the teams and their encounters with the Cameroonian population. As highlighted by the square in the bottom portion of the graph, however, not all team head names are provided in the archival record. This blank spot highlights an important limitation of the data.

Figure 1.2, like the first, highlights the work of specific individuals as the drivers of the mobile health teams. Instead of the individual names, however, figure 1.2 shows instead the professional titles of those leading the mobile teams. Contractual Doctors, Captain

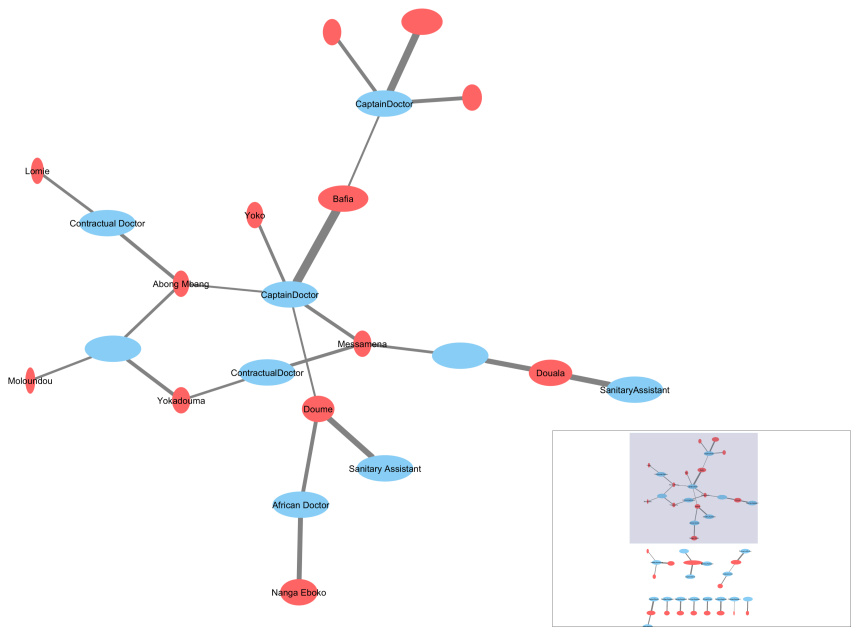

Figure 1.2: Team head titles shown (portion of graph)

Doctor, and Sanitary Assistants were all European medical personnel. The term "African Doctor" represents an official professional rank from the colonial period, designating medical training beyond that of a nurse or auxiliary but below that of a 
French physician. In this case, the choice to shift to representing this data point highlights quite clearly how the prioritization of certain information over others re-enforces the "silences" of the archive. Here, we see in the bottom portion of figure 1.2 that an "African doctor" who goes unnamed was leading one of the teams. Historians naturally gravitate towards identifying clear historical actors, but in this case, prioritizing the ability to name individual medical workers obscures the work of African medical personnel in leading the teams. ${ }^{13}$

Figure 1.3 removes the names and titles of the individuals leading the teams and instead focuses on the administrative number of the teams, when available. When I first worked with this visualization in the context of the Viral Networks workshop, I was concerned about it uncritically reproducing the logic of the colonial state, in that it draws exclusively on French colonial records and their account of

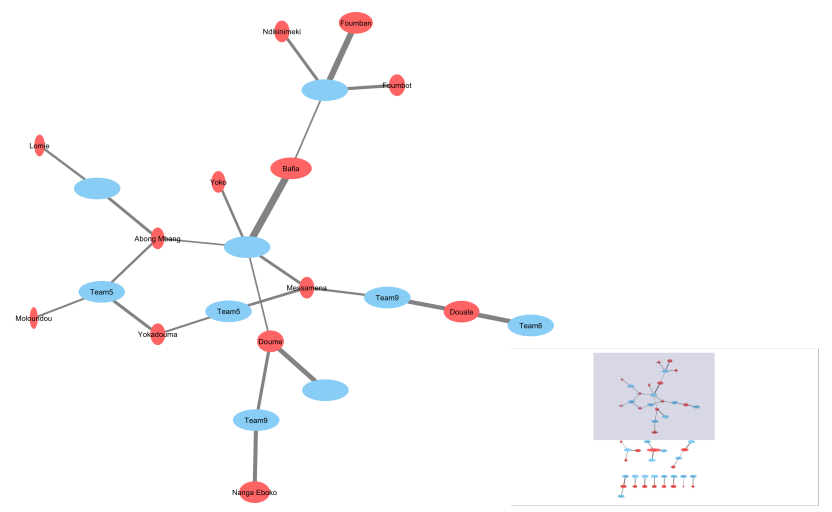

Figure 1.3: Team numbers shown when available, with locations of visits (portion of graph)

the mobile health teams in driving medical interventions in rural Cameroon. However, especially when shown in comparison to the previous graphs, I suggest this visualization also presents an opportunity to move away from a presentation of the work of the teams as driven by the labor of French military doctors. 
While the historiography of French colonial medicine focuses on the central role of these doctors in creating, growing and sustaining the idea of the mobile health service, the removal of their names and the focus on the "team" aspect of the mobile health teams can present a different view. Following the highlighted bottom portion of the graph through the figures, we move from labeling the same node through absence or namelessness, to highlighting the leadership of an African doctor, to highlighting the work of a team of people. These shifts in data presentation in turn correspond to the choice here to "give up" the names of the known European medical personnel. Only by "un-naming" them can we move towards other framings of the data on the mobile health teams.

This is an imperfect outcome still beset by limitations. The records I used to create this dataset and visualization neither name nor provide concrete numbers of the African medical auxiliaries working on each team. Yet, here we might see their organization into units or groups as the main driver of colonial medical intervention in French Cameroon. Moreover, we might see this graph as representing how Cameroonians living in specific locales became connected as well to a network of a new professional class within the colonial state: medical auxiliaries working for the teams.

This diagram also, however, further highlights additional challenges and limitations of my data beyond naming. For example, because I don't have an administrative designation of the mobile teams for many of the visits, I don't know (and can't show) if some teams that here are represented by blank blue nodes were really making visits to multiple locations. Second, this graph does not differentiate for change in the teams over time. The administrative organization of the teams changed over the years so "Team2" is not a static entity, which explains why there are multiple blue nodes with the same team name.

This diagram does, however, present helpful visualizations that can lead to more focused questions on the work of the mobile teams. The portion of the diagram displayed here, for example, shows the relative importance in terms of total population and 
patients seen for locations such as Foumban and Bafia. But it also highlights how relatively smaller locales like Abong Mbang received multiple visits from the teams. This visualization thus invites a return to the records with questions such as why Abong Mbang was a place of importance for the teams over time.

\section{Turning other Absences into Actions}

Throughout the colonial period there existed a significant gap between ideals and reality in the practice of the mobile health teams. First, the teams were chronically under-resourced and staffed and thus fell far short of the aspiration of reaching the whole Cameroonian population. Second, the teams reproduced many oppressive colonial practices and met mixed reactions by Cameroonians. The teams relied on militaristic, often coercive, measures to ensure compliance with medical intervention and had localized histories of medical disaster. ${ }^{14}$

The reaction of Cameroonians to the teams thus grew from complex factors, but colonial officials framed non-compliance as an administrative issue to be overcome. In the 1940s and 50s, medical authorities focused heavily on the percentage of Cameroonians complying with their work as a measure of success. Reaching Cameroonians with biomedical intervention through the mobile health teams remained a central aspiration of the French colonial medical administration throughout the postwar and late colonial period.

Another way to approach this data, and one way that responds to some of the methodological challenges of colonial records, is to create a visualization of colonial framings of medical intervention. The SHMP consistently throughout the 1940s and 50s framed the success and failure of their work through the lens of "absenteeism" on the part of Cameroonians. The service also began to map where absenteeism happened most. ${ }^{15}$ They measured recorded numbers of local populations against the number of people examined during 
a mobile health team visit to calculate the percentage of the local population reached by each visit and, in aggregate, to measure the percentage reached of the total target population for that year.

Subsequently, colonial officials spoke about the relative success of the SHMP's work from year to year in terms of the rise and fall of this number. Officials lamented, for example, that the overall attendance rate to mobile health team visits in 1948 fell to $74.5 \%{ }^{16}$ A governmental decree in June of 1948 rendered medical visits mandatory "for the detection of endemic and epidemic diseases and the treatment of recognized subjects suffering from these diseases." ${ }^{\prime 17}$ Officials attributed a rise in the percentage of people reached by the SHMP the following year, from $74.5 \%$ to $77 \%$, in part to this legislation. ${ }^{18}$

They also, however, recognized limitations to their own collection of data. The population counts for some locales were "fairly old," and they noted that in some places there had been significant emigration towards larger towns, thus suggesting that current populations were smaller than recorded, or as they put it, "justifying" some of the absences. ${ }^{19}$

Moreover, officials framed certain areas of the country through the lens of ethnicity and reported a particular recalcitrance towards the SHMP among these groups. In 1947, for example, the SHMP reported that attendance at visits had fallen overall to below $75 \%$ but in "Bamileké country" to $56 \% .^{20}$ In 1950, officials complained that attendance in some areas had fallen into "ridicule" and again pointed to the Bamileké of Douala as being "particularly distinguished by their indifference." ${ }^{21}$ As anti-colonial nationalist movements took root across southern Cameroon in the 1950s, this map of medical "indiscipline" became, moreover, imbued with ideas about ethnic groups and their ties to these political movements. ${ }^{22}$

Is there potential in creating a visualization of the concerns of colonial officials over compliance with medical interventions? Is there a way to do so such that the visualization offers additional insight beyond what colonial officials saw as a map of "indiscipline"? Addressing these questions fully is beyond the scope of this piece, 
but I raise them to suggest how historians of colonialism and medicine might consider network analysis as a tool for new visual representations of subversions, adaptations, and negotiations around biomedicine in colonial contexts.

\section{Conclusion}

As humanities scholars turn to digital tools and data visualizations, we would do well to keep at the forefront of our minds the kinds of methodologies and approaches that guide our scholarship. ${ }^{23}$ Data visualization can be alluring in its potential to simplify complex ideas, but my experience in the Viral Networks workshop led me to reflect most on how humanities scholars can offer framings of data that preserve complexity.

What I have presented here is a small example of the kinds of choices that humanities scholars must make in presenting visualizations of data. Visualizations that could be used to foreground how a small number of French doctors drove colonial medical interventions can also be reframed to explore how Cameroonians became connected, in both a conceptual and physical sense, through new kinds of relationships between bodies, disease, and medicine. In both recognizing these choices and communicating how they are informed by a much larger context of scholarship and methodological orientation, humanities scholars have an opportunity to continue to bridge disciplines while also insisting that data, and their representation, are never value-free.

\section{Acknowledgments}

I would like to thank the organizers and other contributing scholars of the Viral Networks workshop for their feedback and insights. 


\section{Endnotes}

1. Lauren F. Klein, "The Image of Absence: Archival Silence, Data Visualization, and James Hemings," American Literature 85, no. 4 (December 2013): 661-88.

2. Ann L. Stoler, Along the Archival Grain: Epistemic Anxieties and Colonial Common Sense (Princeton, NJ: Princeton University Press, 2009).

3. After World War II, French Cameroon was a United Nations Trusteeship and the French were thus required to submit yearly reports to the UN on their governance of the territory, including statistics on medical work and health.

4. Steven Feierman, "Struggles for Control: The Social Roots of Health and Healing in Modern Africa," African Studies Review 28, no. 2/3 (1985): 73-147. Feierman points out that "much of the literature about healing in Africa assumes that biomedicine is based on objective knowledge of real phenomena whereas popular medicine is not, and that biomedicine works whereas popular medicine does not." He suggests that all systems of medicine be approached by scholars as forms of "ethnomedicine," that is, they are "products of history" and "embedded with the system of social relations," 105.

5. Helen Tilley, Africa as a Living Laboratory: Empire, Development, and the Problem of Scientific Knowledge, 1870-1950 (Chicago: University of Chicago Press, 2011).

6. Jean-Paul Bado, Eugène Jamot, 1879-1937: Le Médecin de la maladie du sommeil ou trypanosomiase (Paris: Éditions Karthala, 2011). An example of popular commemoration in France comes from the website of the Association Amicale Santé Navale et d'Outremer: www.asnom.org, accessed April 19, 2018.

7. Wang Sonne, Les Auxiliaires Autochtones dans l'Action Sanitaire Publique au Cameroun sous Administration Française, 1916-1945 (PhD diss., Université de Yaoundé, 1983).

8. Benjamin N. Lawrance, Emily Lynn Osborn, and Richard L. Roberts, "Introduction: African Intermediaries and the 'Bargain' of Collaboration," in Intermediaries, Interpreters, and Clerks: African Employees in the Making of Colonial Africa, ed. Lawrance et al. (Madison, WI: University of Wisconsin Press, 2006), 4.

9. Lawrance et al., 5. Mari Webel, "Medical Auxiliaries and the Negotiation of Public Health in Colonial North-Western Tanzania," Journal of African History 54, no. 3 (November 2013): 393-416.

10. Josiane Tantchou, Épidémie et politique en Afrique : Maladie du sommeil et tuberculose au Cameroun (Paris : L'Harmattan, 2007). Noémi Tousignant, "Trypanosomes, Toxicity and Resistance: The Politics of Mass Therapy in French Colonial Africa," Social History of Medicine 25, no. 3 (2012): 625-43. Guillaume Lachenal, Le Médicament qui devait sauver l'Afrique: Un scandale pharmaceutique aux colonies (Paris : La Découverte, 2014). Sarah Cook Runcie, "Mobile Health Teams, Decolonization, and the Eradication Era in Cameroon, 1945-1970" (PhD diss., Columbia University, 2017).

11. Archives, Service historique de la Défense, Toulon, France (SHD). 2013 ZK 005 110, Rapport Annuel, Service de la Santé Publique, Cameroun Français, Année 1950. 
12. Klein, 665.

13. Note: one "African doctor" leading the teams is named in the records for 1947-1951. I have highlighted this particular example to show how a specific historical actor can be lost by focusing on the need for a name.

14. In the most infamous disaster in the 1920s, the teams administered an overdose of the drug tryparsamide and blinded an estimated 700-900 people in Bafia, Bado, 2011. In 1954, the teams administered lomidine injections using contaminated water in Yokadouma, Cameroon. These injections produced bacterial infections, leading to 300 cases of gangrene and 32 deaths. Lachenal (2014), 147-64.

15. Lachenal (2014), 67.

16. SHD 2013 ZK 005 110, Rapport Annuel, Service de la Santé Publique, Cameroun Français, Année 1948, 97.

17. Ibid, 97. Quoting Decree no. 2037, June 1, 1948: "Rendant obligatoire les visites médicales en vue du dépistage des maladies endémo-épidémiques et du traitement des sujets reconnus atteints de ces malade."

18. SHD 2013 ZK 005 110, Rapport Annuel, Service de la Santé Publique, Cameroun Français, Année 1949, 86.

19. SHD 2013 ZK 005 110, Rapport Annuel, Service de la Santé Publique, Cameroun Français, Année 1949, 86.

20. SHD 2013 ZK 005 110, Rapport Annuel, Service de la Santé Publique, Cameroun Français, Année 1947, 111.

21. SHD 2013 ZK 005 110, Rapport Annuel, Service de la Santé Publique, Cameroun Français, Année 1950.

22. Lachenal (2014), 67. Lachenal paraphrases Achille Mbembe in referring to record keeping by the SHMP as a mapping of the "terroirs de lindiscipline," focused on Bamiléké areas.

23. Johanna Druker, "Humanities Approaches to Graphical Display," Digital Humanities Quarterly 5, no. 1(2011). http://www.digitalhumanities.org/dhq/vol/5/ 1/000091/000091.html. Cited in Klein "The Image of Absence." 